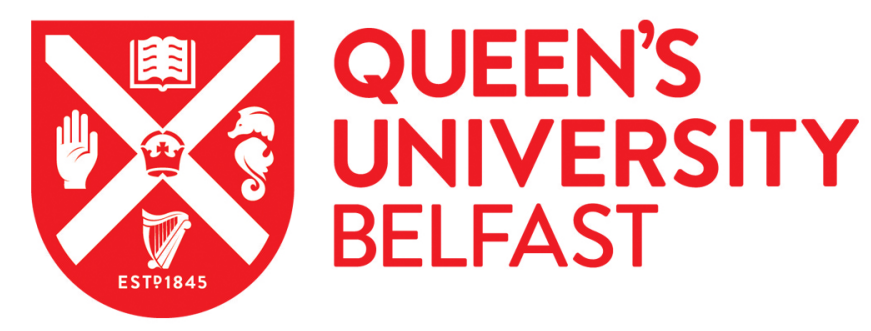

\title{
Endonuclease controlled aggregation of gold nanoparticles for the ultrasensitive detection of pathogenic bacterial DNA
}

McVey, C., Huang, F., Elliott, C., \& Cao, C. (2017). Endonuclease controlled aggregation of gold nanoparticles for the ultrasensitive detection of pathogenic bacterial DNA. Biosensors and Bioelectronics, 92, 502-508. https://doi.org/10.1016/j.bios.2016.10.072

\section{Published in:}

Biosensors and Bioelectronics

\section{Document Version:}

Peer reviewed version

Queen's University Belfast - Research Portal:

Link to publication record in Queen's University Belfast Research Portal

\section{Publisher rights}

(c) 2016 Elsevier B. V. This manuscript version is made available under the CC-BY-NC-ND 4.0 license

http://creativecommons.org/licenses/by-nc-nd/4.0/,which permits distribution and reproduction for non-commercial purposes, provided the author and source are cited.

\section{General rights}

Copyright for the publications made accessible via the Queen's University Belfast Research Portal is retained by the author(s) and / or other copyright owners and it is a condition of accessing these publications that users recognise and abide by the legal requirements associated with these rights.

Take down policy

The Research Portal is Queen's institutional repository that provides access to Queen's research output. Every effort has been made to ensure that content in the Research Portal does not infringe any person's rights, or applicable UK laws. If you discover content in the Research Portal that you believe breaches copyright or violates any law, please contact openaccess@qub.ac.uk. 


\section{Author's Accepted Manuscript}

Endonuclease Controlled Aggregation of Gold Nanoparticles for the Ultrasensitive Detection of Pathogenic Bacterial DNA

Claire McVey, Fumin Huang, Christopher Elliott, Cuong Cao

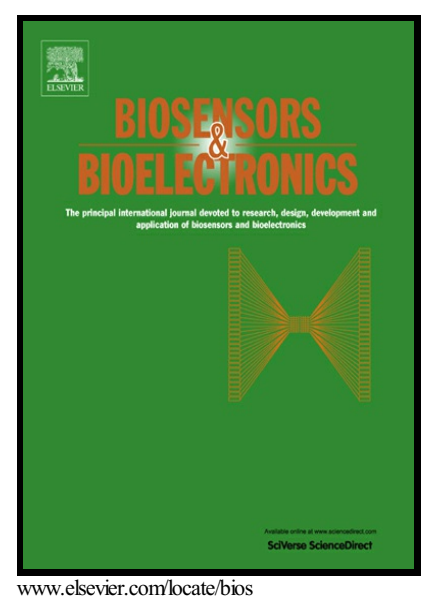

PII: $\quad$ S0956-5663(16)31105-8

DOI: $\quad$ http://dx.doi.org/10.1016/j.bios.2016.10.072

Reference: BIOS9294

To appear in: Biosensors and Bioelectronic

Received date: 11 August 2016

Revised date: 22 October 2016

Accepted date: 25 October 2016

Cite this article as: Claire McVey, Fumin Huang, Christopher Elliott and Cuon६ Cao, Endonuclease Controlled Aggregation of Gold Nanoparticles for th Ultrasensitive Detection of Pathogenic Bacterial DNA, Biosensors an Bioelectronic, http://dx.doi.org/10.1016/j.bios.2016.10.072

This is a PDF file of an unedited manuscript that has been accepted fo publication. As a service to our customers we are providing this early version o the manuscript. The manuscript will undergo copyediting, typesetting, an review of the resulting galley proof before it is published in its final citable form Please note that during the production process errors may be discovered whic could affect the content, and all legal disclaimers that apply to the journal pertain 


\title{
Endonuclease Controlled Aggregation of Gold Nanoparticles for the Ultrasensitive Detection of Pathogenic Bacterial DNA
}

\author{
Claire McVey ${ }^{\mathrm{a}}$, Fumin Huang ${ }^{\mathrm{b}}$, Christopher Elliott ${ }^{\mathrm{a}}$, Cuong $\mathrm{Cao}^{\mathrm{a}^{*}}$
}

${ }^{a}$ Institute for Global Food Security, School of Biological Sciences, Queen's University Belfast, 18-30

Malone Road, Belfast, BT9 5BN, UK

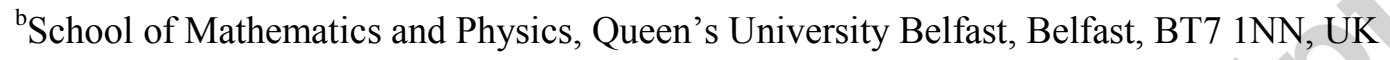

*Corresponding author: Institute for Global Food Security, Northern Ireland Technology Centre (NITC), 18-30 Malone Road, Belfast, BT9 5BN, United Kingdom;

Telephone: +44 (0)28 9097 6545; Email: c.cao@qub.ac.uk

\section{Abstract}

The development of an ultrasensitive biosensor for the low-cost and on-site detection of pathogenic DNA could transform detection capabilities within food safety, environmental monitoring and clinical diagnosis. Herein, we present an innovative approach exploiting endonuclease-controlled aggregation of plasmonic gold nanoparticles (AuNPs) for label-free and ultrasensitive detection of bacterial DNA. The method utilizes RNA-functionalized AuNPs which form DNA-RNA heteroduplex structures through specific hybridization with target DNA. Once formed, the DNA-RNA heteroduplex is susceptible to RNAse $\mathrm{H}$ enzymatic cleavage of the RNA probe, allowing the target DNA to liberate and hybridize with another RNA probe. This continuously happens until all of the RNA probes are cleaved, leaving the nanoparticles unprotected and thus aggregated upon exposure to a high 


\section{ACCEPTED MANUSCRIPT}

electrolytic medium. The assay is ultrasensitive, allowing the detection of target DNA at femtomolar level by simple spectroscopic analysis $(40.7 \mathrm{pM}$ and $2.45 \mathrm{fM}$ as measured by UV-vis and dynamic light scattering (DLS), respectively). The target DNA spiked food matrix (chicken meat) is also successfully detected at a concentration of $1.2 \mathrm{pM}$ (by UV-vis) or $18.0 \mathrm{fM}$ (by DLS). In addition to the ultra-high sensitivity, the total analysis time of the assay is less than 3 hours, thus demonstrating its practicality for food analysis.

Graphical abstract

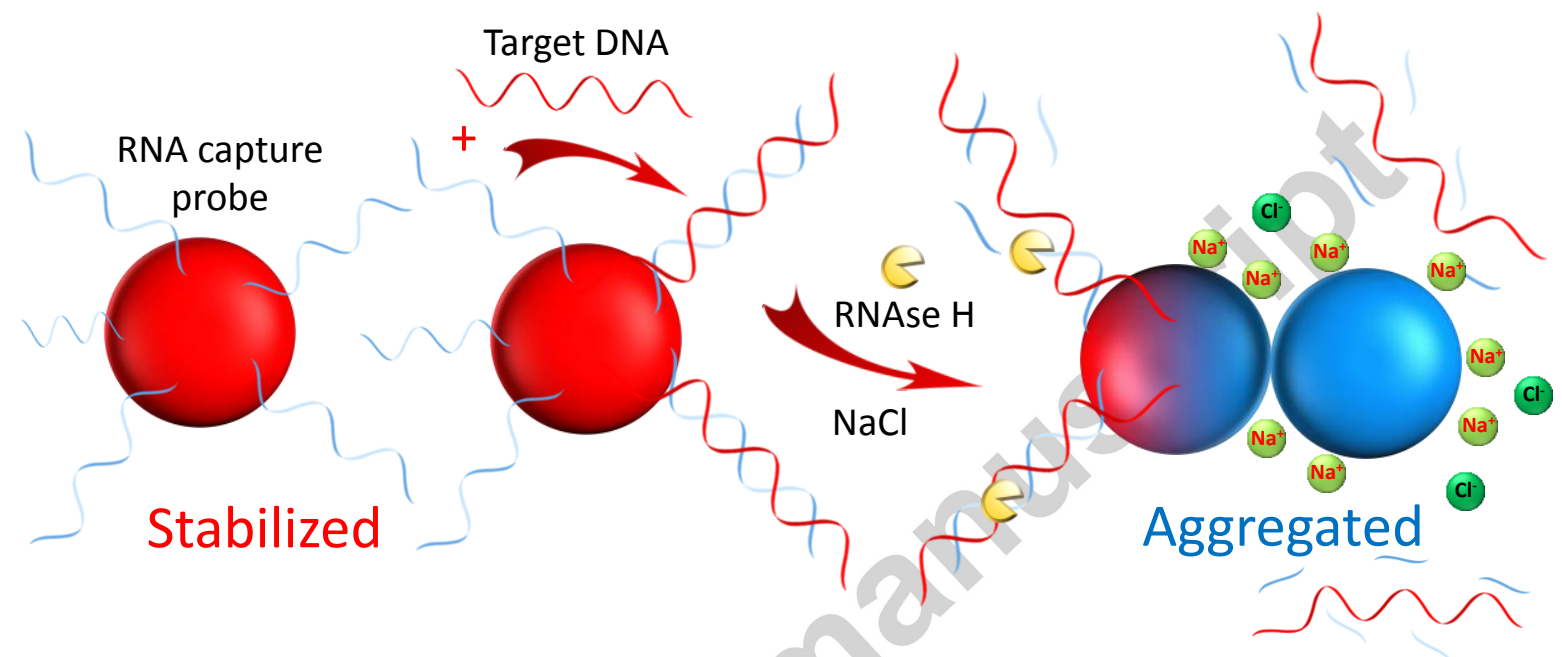

\section{Keywords}

RNAse H, gold nanoparticles, aggregation, DNA detection, endonuclease enzyme

\section{Introduction}

The on-site and sensitive detection of pathogens is of critical importance to the prevention, surveillance and control of infectious diseases and their outbreak at the first onset (Rhode et al., 2015; 


\section{ACCEPTED MANUSCRIPT}

Call et al., 2003; Mothershed and Whitney, 2006). While conventional techniques such as plate culturing, polymerase chain reaction (PCR) and enzyme-linked immunosorbent assay (ELISA) have been used as the predominant detection workhorses, they are limited by either time-consuming and extensive procedure, expensive analysis and operation, or inability to be implemented at point-oftesting (Fratamico, 2003; Brooks et al., 2004; Maurer, 2011; Laurie and Mariani, 2009). Significant efforts have been made to improve the limitations associated with conventional techniques (Lazcka et al., 2007; Baron, 2011; Law et al., 2015). Among these, gold nanoparticles (AuNPs) have emerged as an excellent candidate for biosensor design owing to their unique properties. For example, colloidal AuNPs exhibit distinct colours and strong absorption bands in the visible range of the electromagnetic spectrum that are not present in the bulk metal. This fascinating optical phenomenon of AuNPs is derived from localized surface plasmon resonance (LSPR), a collective oscillation of free electrons in tandem with the incoming photon frequency. This has provided a range of simplified transducing mechanisms for biosensor design, based on assembly, disassembly, or enlargement of the AuNPs which allow scanometric, colorimetric or even naked-eye determination (Cao et al., 2011; Taton et al., 2000; Lee et al., 2007; Zayats et al., 2005; Willner et al., 2006; Pingarron et al., 2008; Verma et al., 2015). Mirkin and co-workers have pioneered and popularized the incorporation of nucleic acidmodified AuNPs into biological sensing platforms to provide improved sensitivity, versatility and portability. Remarkably, the nucleic acid functionalized AuNPs not only provide further functionalities such as specific programmable assembly upon hybridization with their complementary counterparts, but also allow enzymatic cleavage, ligation and extension reactions for biosensor development (Li and Lu, 2000; Palchetti and Mascini, 2008; Lu et al., 2011; Zhao et al., 2008; Thaxton et al., 2006; Wu et al., 2016).

Toward this end, studies have focused on incorporating nuclease enzymes and deoxyribozymes (DNAzyme) to cleave or link oligonucleotides to induce a colorimetric response. DNA endonuclease (DNase I), $\mathrm{Pb}^{2+}$-dependent RNA-cleaving DNAzyme (DNAzyme 8-17), exonuclease III (Exo III) and RNAse $\mathrm{H}$ have been used successfully for the detection of $\mathrm{Pb}^{2+}$, nucleic acids and folate receptor (Zhao et al., 2008; Li et al., 2012; Xu et al., 2009; Cui et al., 2011; Yang and Gao, 2014; Kim et al., 2007; Liu and Lu, 2003; Huang et al., 2012; Fan et al., 2012; Wang et al., 


\section{ACCEPTED MANUSCRIPT}

2011; Kanaras et al., 2007; Kanaras et al., 2007). Zhao and colleagues (2008) utilized DNAzyme 8-17, which cleaves the DNA substrate with a single RNA linkage in the presence of $\mathrm{Pb}^{2+}$ for the detection of metal ions. In a different approach, incorporating the same 8-17 enzyme, Liu and Lu (2003) reported the cross-linking of enzyme-substrate and subsequent cleavage and dissociation of AuNPs upon the addition of target analyte $\left(\mathrm{Pb}^{2+}\right)$. Several groups have also focused on Exo III enzyme which catalyzes the stepwise removal of mononucleotides from blunt or recessed 3'-hydroxyl terminus of duplex DNA (Cui et al., 2011; Yang and Gao, 2014; Huang et al., 2012; Fan et al., 2012). A universal platform was developed by Cui et al. (2011) for the detection of DNA based on Exo III signal amplification. Furthermore, Yang et al. (2014) utilized Exo III for the colorimetric detection of folate receptor, in which the target induced AuNP aggregation. The utilization of Exo III enzyme has proven highly sensitive due to repeated hybridization and hydrolysis reactions. In a different approach, Wang et al. (2011) modified AuNPs with EcoRI enzyme and designed a specific, double stranded DNA probe which contained an EcoRI recognition site and complementary sticky ends. AuNP aggregation occurred in the presence of the target (magnesium and phosphate ions), resulting in a colorimetric response. Although highly successful, such enzymatic approaches are limited by the need for restriction binding sites, extensive probe design, and requirement for further amplification steps. For a comparitive overview of DNA detection, using enzyme-assisted, gold nanoparticles-based transducing platforms see Table SI. 1.

Herein, we present an innovative sensing technology based on the unique enzymatic activity of RNAse $\mathrm{H}$ for the detection of bacterial DNA at concentrations down to femtomolar level. Due to the ubiquitous nature and high levels found in food, especially poultry, Campylobacter jejuni was chosen as the target for assay development (EFSA, 2011; WHO, 2011). The method utilizes RNAfunctionalized AuNPs which form DNA-RNA heteroduplex structures through specific hybridization with target DNA. Once formed, the DNA-RNA heteroduplex is susceptible to RNAse H enzymatic cleavage of the RNA probe, allowing DNA to liberate and hybridize with another RNA strand. This continuously happens until all of the RNA strands are cleaved, leaving the nanoparticles unprotected and prone to aggregation upon exposure to a high electrolytic medium. The current work overcomes previous limitations associated with enzyme-based methods in that it does not require further 


\section{ACCEPTED MANUSCRIPT}

amplification steps. In addition, RNAse $\mathrm{H}$ is not active on single stranded DNA or RNA molecules and only catalyzes the cleavage of RNA within a DNA-RNA heteroduplex, thus does not require specific recognition sites for enzymatic cleavage (Tadokoro and Kanaya, 2009). Furthermore, there is greater versatility and applicability with regard to probe design and thus potential for multiplexing. RNAse $\mathrm{H}$ has previously been used for the detection of DNA via RNA cleavage within a DNA-RNA heteroduplex structure and subsequent release of a fluorescence dye to generate a fluorescence signal (Kim et al, 2007). The method has a limit of detection (LOD) of $10 \mathrm{pM}$, which highlights the ultrasensitivity of our method which can determine target DNA at $1 \mathrm{pM}$ by naked eye, or even down to femtomolar level by spectroscopic analysis. The fluorescence-based approach is further limited by cost due to the synthesis of fluorescein conjugate and requirement for equipment capable of detecting the fluorescence signals. Our work is significantly different from previous reports as it utilizes the plasmonic properties of AuNPs to produce a red-to-blue colorimetric response, thus the signal can be visibly detected by the naked eye. In addition, DNA detection can be performed at isothermal conditions in less than three hours. These advantages provide a basis for eradicating the need for a thermal cycler, complicated sample preparation, labelled fluorophore and expensive and cumbersome read-out equipment. Finally, the application to a food matrix has also been assessed and it is evident that the sensitivity and robustness of the assay is conducive for food safety analysis.

\section{Experimental Section}

\subsection{Reagents and chemicals}

Aminated RNA probe (5'-Amino-C6-AGG UGU GGA CGA CGU CAA GUC AUC AUG-3'), complementary DNA probe (5'-CAT GAT GAC TTG ACG TCG TCC ACA CCT-3'), noncomplementary DNA probe 1 (5'-CCA ACC CCC CAG AAA GAA-3') and non-complementary probe 2 (5'-TCT ATT GGT GGT AAA ACT TAC GCT GCA AGT AAA GCC GAA GGT CAC -3') were purchased from Eurofins Genomics (Ebersburg, Germany). RNAse H enzyme was purchased from Takara Bio (France), and thioctic acid NHS ester was obtained from Link Technology Ltd. (UK). Sodium citrate tribasic dehydrate $\left(\mathrm{HOC}(\mathrm{COONa})\left(\mathrm{CH}_{2} \mathrm{COONa}\right)_{2} \cdot 2 \mathrm{H}_{2} \mathrm{O}\right)$, gold (III) chloride $\left(\mathrm{HAuCl}_{4}\right)$, dimethyl sulfoxide (DMSO) $\left(\left(\mathrm{CH}_{3}\right)_{2} \mathrm{SO}\right)$, Tween 20 , sodium chloride $(\mathrm{NaCl})$, sodium carbonate 


\section{ACCEPTED MANUSCRIPT}

$\left(\mathrm{Na}_{2} \mathrm{CO}_{3}\right)$, sodium bicarbonate $\left(\mathrm{Na}_{2} \mathrm{HCO}_{3}\right)$, triethylammonium acetate buffer (TEAA), sodium phosphate $\left(\mathrm{NaH}_{2} \mathrm{PO}_{4}\right.$ and $\left.\mathrm{Na}_{2} \mathrm{HPO}_{4}\right)$, glutathione (GSH), Tris-EDTA buffer (TE), Tris-HCl $\left(\mathrm{NH}_{2} \mathrm{C}\left(\mathrm{CH}_{2} \mathrm{OH}\right)_{3}\right)$, hydrochloric acid $(\mathrm{HCl})$, potassium chloride $(\mathrm{KCl})$, magnesium chloride $\left(\mathrm{MgCl}_{2}\right)$ and dithiothreitol (DTT) were purchased from Sigma-Aldrich (UK). All reagents were prepared in RNAse free water (Sigma, UK). NAP-5 column was obtained from GE Healthcare (UK). Syringe filters $(0.22 \mu \mathrm{m})$ were purchased from Merck Millipore (Germany).

\subsection{Gold nanoparticle synthesis}

In a typical experiment, $25 \mathrm{mM} \mathrm{HAuCl} \mathrm{H}_{4}$ was dissolved in $150 \mathrm{~mL}$ of deionized $\mathrm{H}_{2} \mathrm{O}\left(\mathrm{dH}_{2} \mathrm{O}\right)$ and heated to reflux under constant stirring ( $\mathrm{t} \approx 10$ minutes). $1 \mathrm{~mL}$ of $2.4 \mathrm{mM}$ sodium citrate was quickly injected and the solution was removed from the heat upon the color changed from translucent yellow to wine red. The $\mathrm{pH}$ of the solution was adjusted to $6.5 \mathrm{using} \mathrm{HCl}$.

\subsection{RNA preparation}

Prior to functionalisation the RNA was modified with thiotic acid at the 5' end (Dougan et al, 2007). The dried RNA was incubated with $30 \mu \mathrm{L}$ of $80 \mathrm{mM}$ thiotic acid (dissolved in DMSO) and 75 $\mu \mathrm{L}$ of $0.1 \mathrm{M} \mathrm{Na}_{2} \mathrm{CO}_{3} / \mathrm{NaHCO}_{3}(\mathrm{pH} 9.75$ ) overnight at room temperature. The modified RNA was desalted using a NAP-5 column in 0.1 M TEAA buffer. The concentration was determined using Nanodrop 8000 (Thermoscientific, UK).

\subsection{Gold nanoparticle functionalization}

Gold nanoparticles were functionalized with the as-prepared RNA. Typically, $300 \mu \mathrm{L}$ of 30 $\mu \mathrm{M}$ modified RNA was added to $1 \mathrm{~mL}$ of AuNP solution. The solution was incubated overnight $(\mathrm{t} \approx 16$ hours) at room temperature and stability checked with an equal volume of $4 \mathrm{M} \mathrm{NaCl}$ to ensure successful conjugation. To improve the orientation and loading of RNA conjugated onto the surface of the AuNP, the salt concentration was slowly increased (Hurst et al, 2006). Firstly, phosphate buffer $(60 \mathrm{mM})$ was diluted to a final concentration of $10 \mathrm{mM}$. $\mathrm{NaCl}$ was added in small increments $(0.05 \mathrm{M})$ each hour, over six hours $(0.3 \mathrm{M})$. The conjugate was incubated overnight ( $\mathrm{t} \approx 16$ hours) at room 


\section{ACCEPTED MANUSCRIPT}

temperature. Finally, the conjugate was centrifuged twice at $13,000 \mathrm{~g}$ for 1 hour to remove unbound RNA and re-suspended in TE buffer (stored at $4^{\circ} \mathrm{C}$ ).

\subsection{Determination of AuNP-RNA stability}

In order to ensure the colloidal stability of the RNA-functionalized AuNPs at high salt concentrations, the conjugates were exposed to different concentrations of $\mathrm{NaCl}$ (Figure SI. 2). The functionalized particles exhibit excellent stability at $2 \mathrm{M} \mathrm{NaCl}$, with no wavelength shift noted. The bare-AuNPs immediately aggregated at $0.5 \mathrm{M} \mathrm{NaCl}$, due to the large screening effect of $\mathrm{NaCl}$, causing a red-shift to longer wavelengths on the absorbance spectrum $\left(\lambda_{\max }\right.$ shift $\left.>200 \mathrm{~nm}\right)$. This stability can be attributed to electrostatic repulsion or steric exclusion caused by RNA on the AuNP surface. From this analysis, successful functionalisation was confirmed and $2 \mathrm{M} \mathrm{NaCl}$ was set as the highest concentration to induce aggregation of AuNPs over varying stabilities.

\subsection{Colorimetric detection of pathogenic bacterial DNA}

Prior to analysis, the AuNP conjugate was centrifuged (13,000 g for 30 minutes) and resuspended in a modified Tris- $\mathrm{HCl}$ buffer $\left(20 \mathrm{mM}\right.$ Tris, $40 \mathrm{mM} \mathrm{KCl}, 8 \mathrm{mM} \mathrm{MgCl} \mathrm{M}_{2}$ and $1 \mathrm{mM}$ DTT). 30 $\mu \mathrm{M}$ GSH was also added to this buffer due to its role in aiding RNAse $\mathrm{H}$ enzyme activity (Lyles and Gilbert, 1991). In a typical experiment $20 \mu \mathrm{L}$ of AuNP-RNA was added into an Eppendorf tube with $10 \mu \mathrm{L}$ of target DNA or control (modified Tris-buffer) and $1.5 \mu \mathrm{L}$ of Tween 20 . The sample was heated to $90{ }^{\circ} \mathrm{C}$ for 2 minutes, cooled slowly to $60{ }^{\circ} \mathrm{C}$ and incubated at $60{ }^{\circ} \mathrm{C}$ for 60 minutes. $0.06 \mathrm{U}$ of RNAse $\mathrm{H}$ enzyme, prepared in modified Tris-buffer, was added to a final concentration of $0.02 \mathrm{U}$. The sample was then incubated for 1 hour at $37{ }^{\circ} \mathrm{C}$. To induce aggregation, $\mathrm{NaCl}$ was added into the mixture to a final effective concentration of $2 \mathrm{M}$.

\subsection{Preparation of DNA in chicken matrix}

$50 \mathrm{~g}$ of skinless chicken meat (breast) was shaken for 2 minutes in $100 \mathrm{mM}$ Tris- $\mathrm{HCl}(\mathrm{pH} 7)$. The subsequent matrix was filtered and diluted $1 / 100$ in modified Tris- $\mathrm{HCl}$ buffer ( $20 \mathrm{mM}$ Tris, 40 


\section{ACCEPTED MANUSCRIPT}

$\mathrm{mM} \mathrm{KCl}, 8 \mathrm{mM} \mathrm{MgCl} 2$ and $1 \mathrm{mM} \mathrm{DTT}$ ). This matrix was then used to prepare a 10-fold dilution of target DNA ranging from 0 to $10 \mu \mathrm{M}$ concentration.

\subsection{Analysis instrumentation}

All Ultraviolet-visible spectrophotometry (UV-vis) measurements were carried out using a Cary 60 spectrophotometer (Agilent Technologies, USA). AuNP size analysis was carried out using a Zetasizer NanoZS (Malvern, UK). Transmission electron microscopy (TEM) characterization was acquired using a Phillips CM100 (Phillips, USA) operated at $100 \mathrm{kV}$.

\section{Results and discussion}

3.1 Working principle of the colorimetric assay

A: In the presence of target DNA

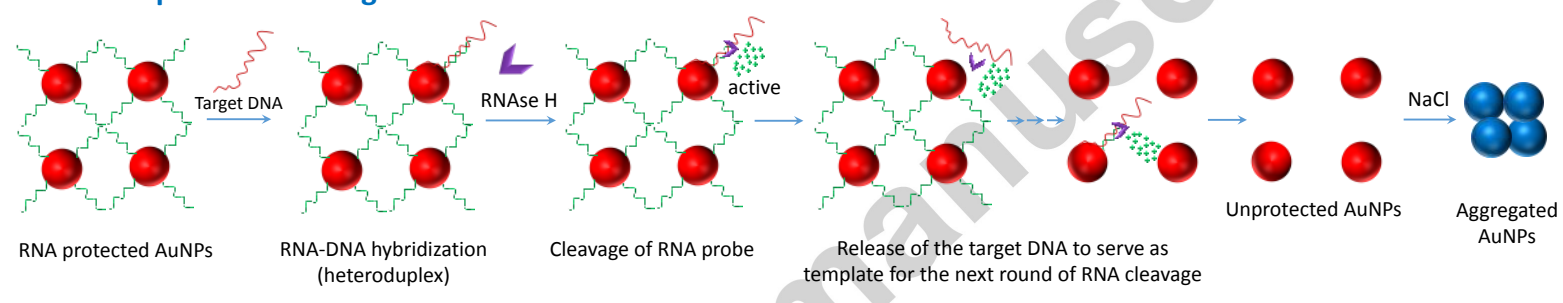

B: In the absence of target DNA

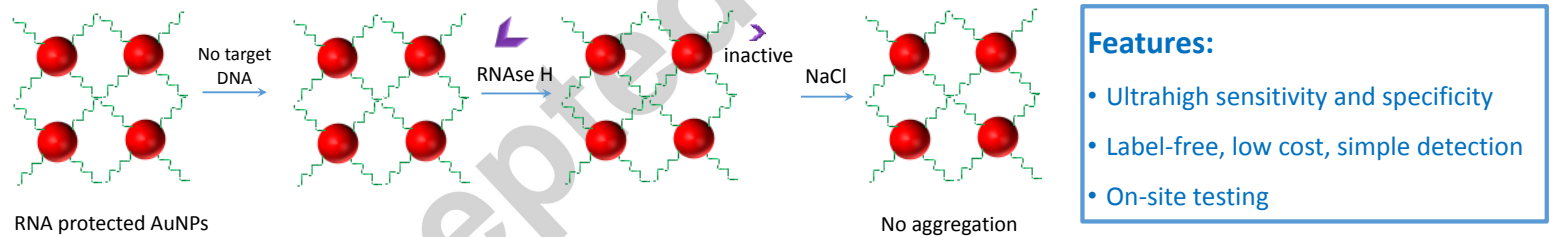

Figure 1. Overall scheme demonstrating the colorimetric detection of target DNA based on DNARNA hybridization and enzyme controlled cleavage and aggregation of AuNPs upon the addition of NaCl. (A) In the presence of target DNA, DNA-RNA hybridization occurs which initiates RNAse H enzyme cleavage of RNA within the heteroduplex structure. The target DNA recycles until all of the RNA is cleaved, allowing for subsequent AuNP aggregation in the presence of $\mathrm{NaCl}$. (B) In the absence of target DNA, no hybridization occurs, thus there is no heteroduplex structure to act on and the RNAse $\mathrm{H}$ enzyme is inactive. Therefore the particles remain stable upon the addition of $\mathrm{NaCl}$. 


\section{ACCEPTED MANUSCRIPT}

AuNPs (17 $\pm 3 \mathrm{~nm}$, Figure SI. 3) were first synthesized by a method reported previously with minor alterations (Turkevich et al, 1951) and exhibited a typical UV-vis absorbance band at $520 \mathrm{~nm}$. Subsequently, a single-stranded RNA probe (5'-Amino-C6 -AGG UGU GGA CGA CGU CAA GUC AUC AUG -3') was designed to recognize a DNA fragment of Campylobacter jejuni, (NCTC $11168=$ ATCC 700819 chromosome, 5'-CAT GAT GAC TTG ACG TCG TCC ACA CCT-3'). The RNA probe was successfully crafted onto the AuNP via an N-hydroxysuccimidyl (NHS) ester of thioctic acid by a method reported by Dougan et al. (2007). The AuNP-RNA conjugate exhibits a deep red colour, and absorbance peaks at $525 \mathrm{~nm}$ and $260 \mathrm{~nm}$ (Figure SI. 4), which represents the typical optical absorption of AuNPs and RNA, respectively. The shift in LSPR peak from $520 \mathrm{~nm}$ (bare nanoparticles), to $525 \mathrm{~nm}$ with the AuNP-RNA conjugates further demonstrates the successful functionalisation. The RNA-functionalized AuNPs prepared by this method show excellent stability, their plasmonic and biological properties could be retained upto 4 weeks with storage in TE buffer, at $4^{\circ} \mathrm{C}$. In the presence of target Campylobacter jejuni DNA, hybridization occurs with RNA functionalized onto the AuNP surface. The subsequent DNA-RNA heteroduplex becomes a target for cleavage of the RNA probe via RNAse H enzyme, allowing the DNA to liberate and hybridize with another RNA strand (Figure 1, overall scheme). This happens isothermally and iteratively until all of the RNA probes are cleaved, leaving the nanoparticles denuded. The addition of $2 \mathrm{M} \mathrm{NaCl}$ causes the denuded nanoparticles to aggregate in solution, initiating a colour change from red to blue. The aggregation state was confirmed in Figure 2 by the transmission electron microscopy (TEM) analysis of RNA-functionalized AuNPs under assay conditions in the absence and presence $(1 \mu \mathrm{M})$ of target DNA. The distinct colour change generated from the assay can be detected by the unaided eye, or by simple spectroscopic analysis.
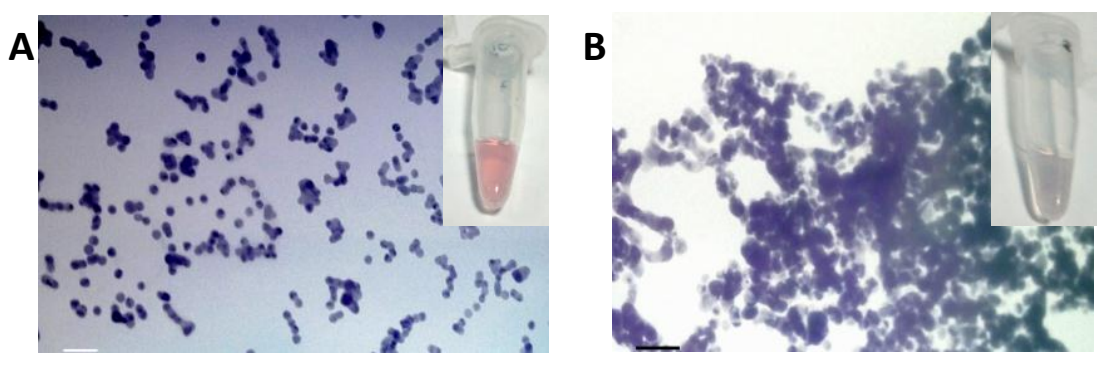


\section{ACCEPTED MANUSCRIPT}

Figure 2. Transmission electron microscopy (TEM) images and photographs of the colorimetric response of AuNPs in the (A) absence and (B) presence of target DNA $(1 \mu \mathrm{M})$ post assay conditions. Scale bar $100 \mathrm{~nm}$.

\subsection{Sensitivity of assay}

To test the hypothesis of the assay, a 10-fold dilution of target DNA ranging from 0 to $10 \mu \mathrm{M}$ concentration was analyzed. Figure 3A demonstrates the visible colour change of AuNP-RNA solution from red to blue or grey, with increasing target DNA concentration. The lowest target DNA concentration easily determined by the naked eye was $10^{-6} \mu \mathrm{M}$, as seen by a colour change from red to light blue, caused by a decrease in interparticle distance. More quantitatively, UV-vis absorption measurements were performed to determine the LSPR shift as a function of target DNA concentration (Figure 3B). The results demonstrate a shift in wavelength from a target DNA concentration of $10 \mathrm{fM}$, which continues to increase to $10 \mu \mathrm{M}$ (Figure 3C). A good linear relationship between the LSPR shift and target DNA concentration (Figure 3C, inset) could be obtained for a range between $10 \mathrm{fM}$ and 10 $\mu \mathrm{M}$ of target DNA $\left(\mathrm{R}^{2}=0.93\right)$. The limit of detection (LOD) is defined as the lowest DNA concentration with a response three times greater than the standard deviation (SD) of the blank sample. Owing to the excellent stability of the AuNP-RNA conjugate, the SD value of the zero concentration for ten measurements $(\mathrm{n}=10)$ was as small as $1.9 \mathrm{~nm}$, thus the LOD of the current assay is $40.7 \mathrm{fM}$ of pathogenic bacterial DNA. The LOD is about two orders of magnitude more sensitive in comparison to a similar method utilizing fluorescein (Kim et al., 2007) and other AuNP-functionalized based assays for the detection of DNA (Cui et al., 2011; Fan et al., 2012).

During the UV-vis analysis, we observed that the aggregated AuNPs had latched on to the wall of the Eppendorf tube or settled down to the bottom of the tube, potentially causing only free and partially aggregated particles to be measured in solution. Thus, it is evident that the LSPR shift (Figure 3B) is not as predominant when compared to the colorimetric response as seen in the colour photographs. Therefore, to accurately reflect the aggregation states of the AuNPs, dynamic light scattering (DLS) measurements were carried out to determine the average size of the AuNP-conjugates in the presence varying target DNA concentrations. DLS data is displayed as the integrated value of three measurements derived from one sample. The polydispersity index (PDI) for each sample is also 


\section{ACCEPTED MANUSCRIPT}

displayed which indicates the variation of nanoparticle size within a distribution. The PDI is calculated from the distribution width and mean, giving an overall indication of the non-uniformaty of particles within a sample. The DLS results show an average increase in AuNP size, from $44.4 \mathrm{~nm}( \pm 1.2 \mathrm{~nm})$ with the zero concentration sample to $854.0 \mathrm{~nm}( \pm 36.0 \mathrm{~nm})$ at $1 \mu \mathrm{M}$ target DNA concentration, which demonstrates increased aggregation with increasing target DNA concentration (Figure 3D). Furthermore, the size distribution charts show a shift in average size from one population, between 10 $-100 \mathrm{~nm}$ to a second, increasing population (100 to $1000 \mathrm{~nm}$ ). This large size distribution can be explained by the highly sensitive nature of DLS analysis which is capable of determining the true state of particles in a given media, compared to TEM which only measures the solid state (nanoparticles are dried on grid subsequent to analysis). Furthermore, DLS measures the hydrodynamic diameter of the particle, which in this case includes the metallic core and RNA functionalised onto the surface, thus it is obvious that we should see this wide distribution (Domingos et al, 2009). The PDI data demonstrates broad polydispersion which increases from $0 \mu \mathrm{M}$ to $10^{-3} \mu \mathrm{M}$ target DNA concentration, where the index value decreases. This indicates a wide size distribution at lower target DNA concentrations, with narrower size distributions at higher concentrations. This coincides with the distribution data which indicates that there are a greater number of larger or aggregated particles at a high target DNA concentration, in contrast with lower target DNA concentrations which demonstrate a larger size frequency over serveral distribution sizes (i.e. 10-100 $\mathrm{nm}$ and 100-1000 nm). Figure 3E demonstrates the linear fitting of AuNP size increase as a function of target DNA concentration $\left(R^{2}=0.98\right)$. This data provides a dynamic range of between $1 \mathrm{fM}$ and 100 pM of target DNA. From this data we can determine a LOD of $2.45 \mathrm{fM}$ which is not clearly discriminable to the naked-eye or detectable using UV-vis spectrophotometry. A baseline has been included in Figure 3E to remove background signal as determined by specificity and selectivity analysis. 


\section{ACCEPTED MANUSCRIPT}

A $0=10^{-9} \quad 10^{-6} \cdot 10^{-3} \cdot 10^{-1}=1,10 \mu \mathrm{M}$

B

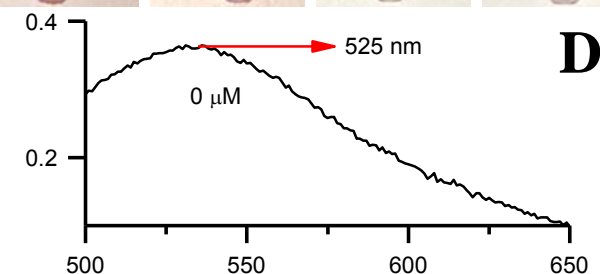

D $\quad D_{H}=44.4 \pm 1.2 \mathrm{~nm} \quad P D I=0.476 \pm 0.04$
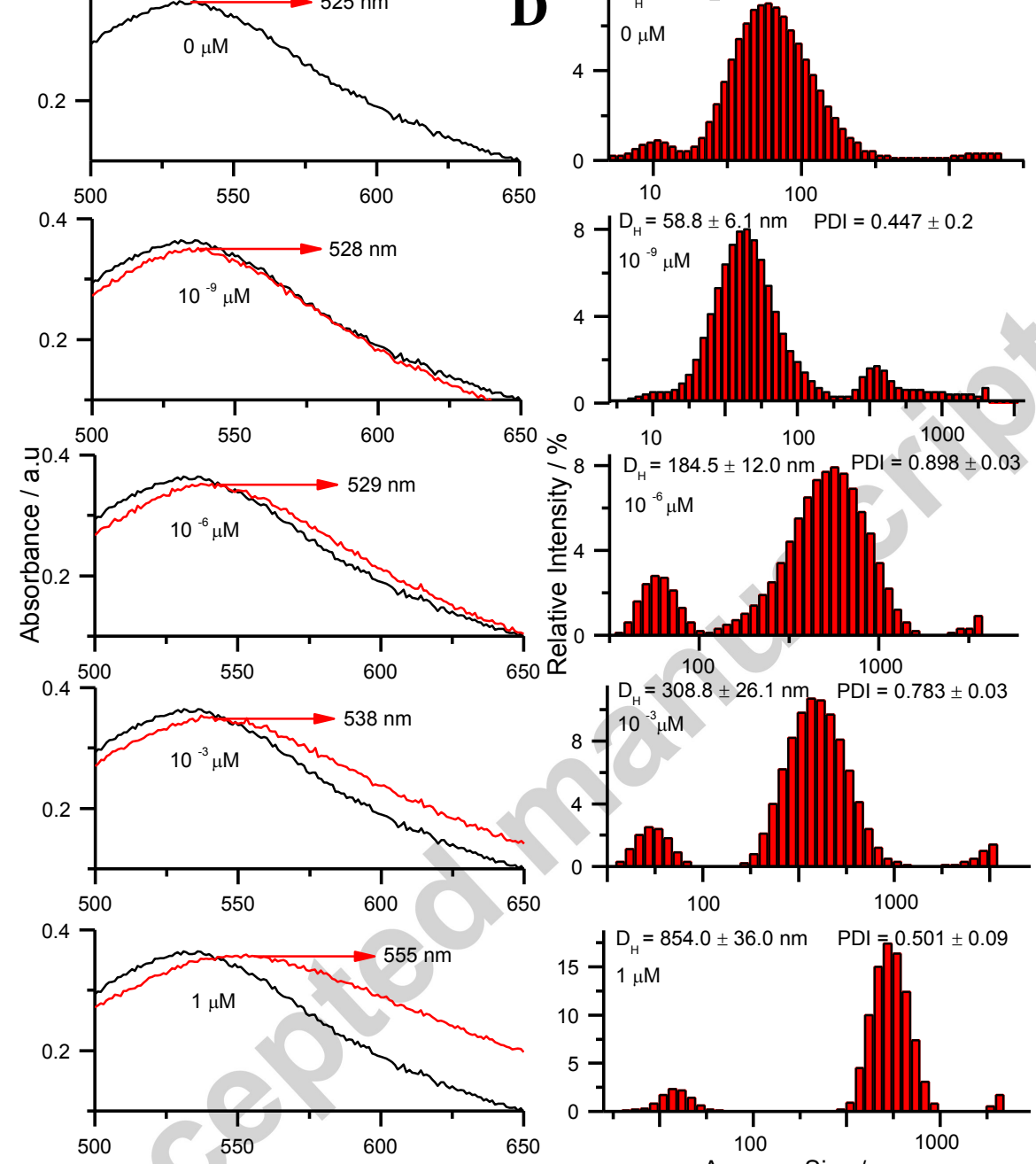

C

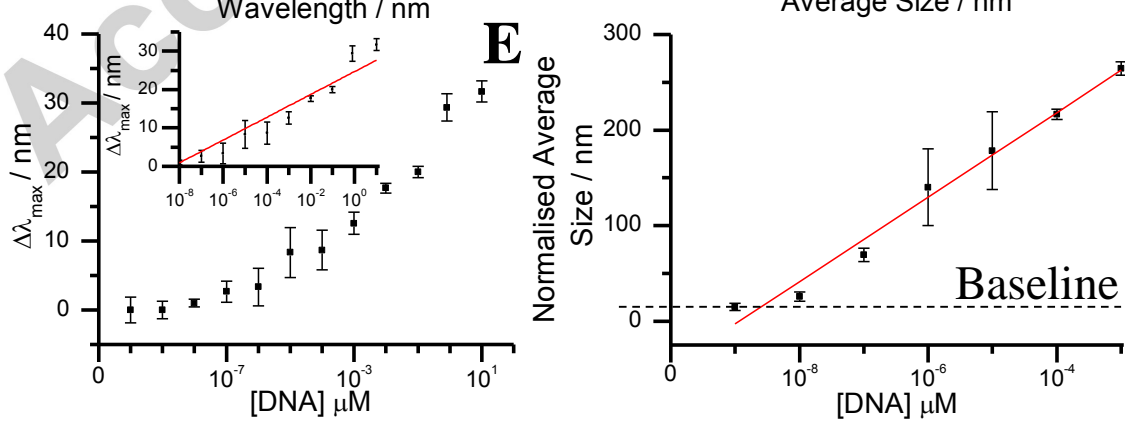

Figure 3. Analysis of AuNP-RNA conjugates in the presence of increasing concentrations of target DNA. (A) A representative colour photograph showing a visual colour change from red to blue or transparent with increasing DNA concentrations. (B) UV-vis absorption spectra demonstrating a red 


\section{ACCEPTED MANUSCRIPT}

shift towards longer wavelengths $(525 \mathrm{~nm}$ to $555 \mathrm{~nm})$ in the presence of increasing target DNA concentrations. (C) Wavelength shift of the LSPR peak as a function of target DNA concentration $(\mathrm{n}=$ 3). Inset: the linear relationship between target DNA concentration and maximum wavelength shift $\left(\mathrm{R}^{2}\right.$ $=0.93)(\mathrm{D})$ Hydrodynamic size distribution of AuNPs measured by dynamic light scattering (DLS) technique (inset PDI). (E) Linear relationship between target DNA concentration and average increase in AuNP size derived from DLS analysis $\left(\mathrm{R}^{2}=0.98\right)$.

\subsection{The selectivity of the assay}

Control experiments were carried out with RNAse $\mathrm{H}$ enzyme removed to determine if nanoparticle aggregation was fully attributed to the enzymatic cleavage of RNA (target DNA concentration was fixed at $10 \mu \mathrm{M})$. In the absence of target DNA but in the presence of RNAse $\mathrm{H}$ enzyme, the average AuNP size was determined to be $44.4 \pm 1.2 \mathrm{~nm}$ (Figure 4A) with no visible change in colorimetric response (Figure 4B) and no shift in LSPR peak (maximum absorbance peak at $525 \mathrm{~nm}$; Figure 4C). In the absence of RNAse $\mathrm{H}$ but in the presence of $10 \mu \mathrm{M}$ target DNA, the hybridization of the RNA-DNA resulted in an increase in the average size of the nucleotide-AuNP complex of $24.8 \mathrm{~nm}$ as compared to the zero (no target) sample (Figure 4A). The UV-vis results further demonstrate that the removal of RNAse $\mathrm{H}$ enzyme results in almost no change in the LSPR peak shift. This result confirms that the addition of RNAse $\mathrm{H}$ enzyme is essential in controlling aggregation of the AuNPs through cleavage of functionalised RNA.

Control experiments were also carried out with two non-complementary DNA sequences at a concentration of $10 \mu \mathrm{M}$. The DLS results demonstrate a slight increase in particle complex size with a maximum value of $9.6 \mathrm{~nm}$ (Figure 4A), attributing to the background noise of the assay (also denoted as the baseline on Figure 3E). The colour images in Figure 4B along with the UV-vis results (Figure 4C) demonstrate no visual or spectroscopic change in colour or LSPR peak under the test experiments. The high specificity of the assay can be credited to the specific DNA-RNA recognition and hybridisation, as well as subsequent highly selective RNAse H enzyme cleavage of the RNA in the heteroduplex. 

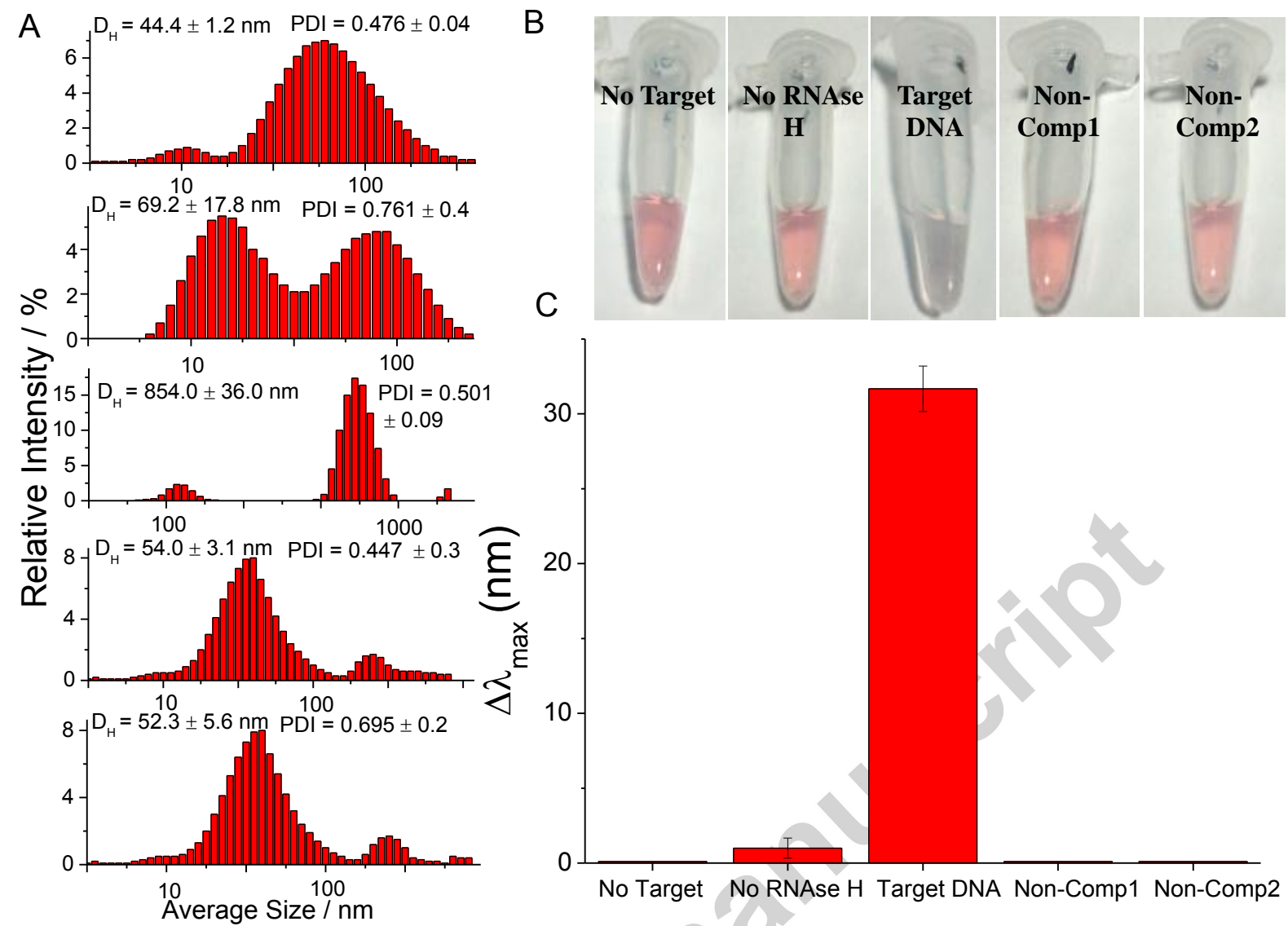

Figure 4. Illustrating the assay specificity. (A) DLS measurements demonstrating the hydrodynamic size distribution of AuNP-RNA post assay conditions. From top to bottom: RNAse H enzyme and 0 $\mu \mathrm{M}$ target DNA; no RNAse $\mathrm{H}$ enzyme and $10 \mu \mathrm{M}$ target DNA; RNAse $\mathrm{H}$ enzyme and $1 \mu \mathrm{M}$ target DNA; RNAse $\mathrm{H}$ enzyme and $10 \mu \mathrm{M}$ non-complementary DNA sequence 1; and RNAse $\mathrm{H}$ enzyme and $10 \mu \mathrm{M}$ non-complementary DNA sequence 2. (B) and (C) are the corresponding colour photograph and maximum wavelength shift of LSPR peak under different conditions $(n=3)$, respectively.

\subsection{Application to real sample matrices}

The applicability of the assay was tested by preparing a 10 -fold dilution of target DNA ranging from 0 to $10 \mu \mathrm{M}$ in chicken matrix. The aim of this experiment was to determine if the assay could be applided to a food matrix, given the complex medium and thus potential interferences and inhibitors that could cause deteroration of assay parameters such as reduced sensitivity and specificity. Figure 


\section{ACCEPTED MANUSCRIPT}

5A shows the maximum LSPR shift, as a function of target DNA in chicken matrix. The results demonstrate good linearity $\left(\mathrm{R}^{2}=0.96\right)$ spanning from $10 \mathrm{fM}$ and $10 \mu \mathrm{M}$. In the complex environment, the spiked target DNA was identified at a concentration as low as $1.2 \mathrm{pM}$ based on the LSPR analysis. It was noted that the LOD had increased two orders of magnitude in comparison to buffer conditions and there was an overall decrease in maximum LSPR shift $(15 \mathrm{~nm})$, which might be attributable to interferences of the enzymatic reaction within the sample. Furthermore, parallel DLS measurements were carried out to determine the aggregation states of AuNPs post analysis in chicken matrix. Figure 5B demonstrates the linear correlation between normalized average size $(\mathrm{nm})$ and DNA concentration $(\mu \mathrm{M})$. The linear range of the assay was determined to be between $10 \mathrm{fM}$ and $1 \mu \mathrm{M}$, with a limit of detection of $18.0 \mathrm{fM}$. In addtion, the comercial availability of portable and battery operated UV-Vis spectophotometers and particle size analyzers makes on-site detection using the developed assay highly possible in case where imporved sensitivity is required beyond that of naked eye detection (Ocean Optics, 2016; Xylem, 2016; TSI, 2016). Thus, the assay shows potential application to food analysis.
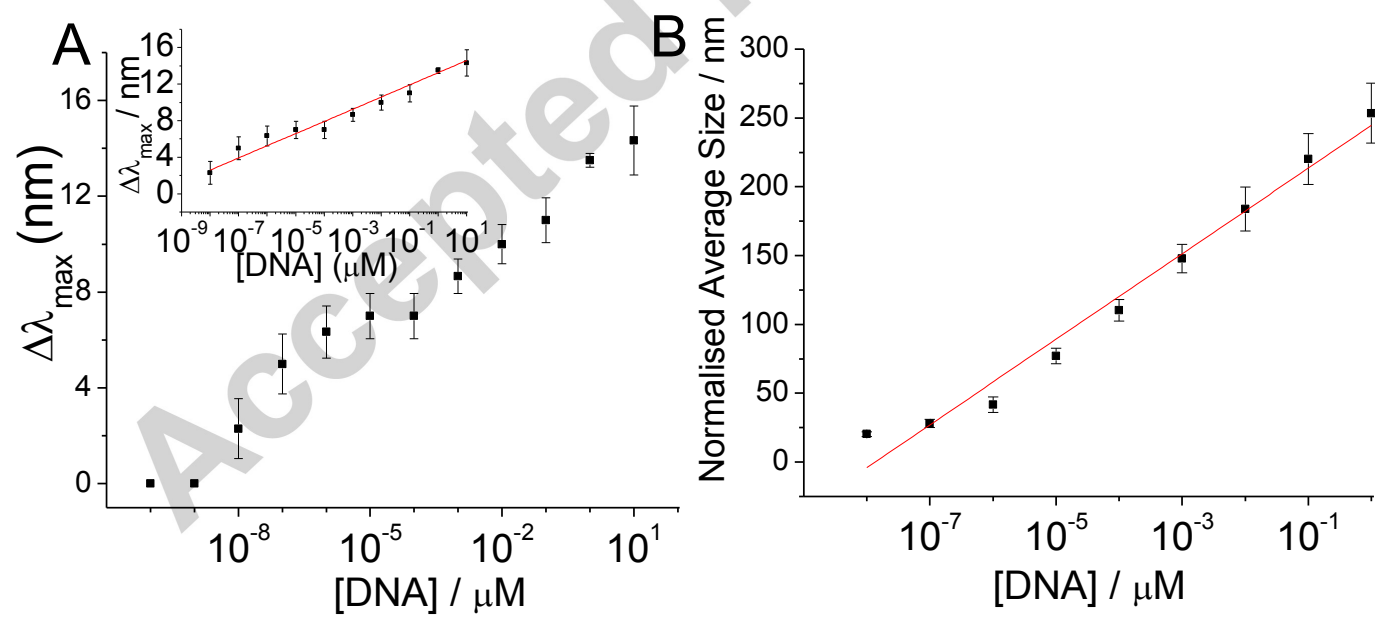

Figure 5. (A) Wavelength shift of the LSPR peak as a function of target DNA concentration analyzed in chicken matrix, demonstrating the sensitivity of the assay. Inset is the linear relationship between target DNA concentration spiked in chicken matrix and maximum wavelength shift $\left(\mathrm{R}^{2}=0.96\right)$. 


\section{ACCEPTED MANUSCRIPT}

Linear relationship between target DNA prepared in chicken matrix and normalized, average increase in nanoparticle size determined by dynamic light scattering technique (DLS) $\left(\mathrm{R}^{2}=0.98\right)$.

\section{Conclusion}

In conclusion, we have presented a highly sensitive and selective method for the detection of DNA, based on endonuclease controlled aggregation of plasmonic AuNPs. RNAse H enzymatic cleavage in combination with DNA-RNA hybridization provides a highly specific and ultra-sensitive assay, which can detect $1 \mathrm{pM}$ target DNA concentration visibly or down to femtomolar level by spectroscopic techniques ( $40.7 \mathrm{fM}$ and $2.45 \mathrm{fM}$ as measured by UV-vis and dynamic light scattering (DLS), respectively). The detection capabilities within a food matrix show good sensitivity (1.2 pM and $18.0 \mathrm{fM}$ as analyzed by UV-vis and DLS, respectively). In addition to the ultra-high sensitivity, the total analysis time of the assay is less than 3 hours, thus demonstrating its practicality for food analysis. The versatility of probe design and enzyme cleavage offers a broad range of potential applications for the detection of DNA. Future work will focus on further applications of the method and potential multiplexing capabilities for real clinical and veterinary samples.

\section{Conflict of interest}

The authors have no conflict of interest to declare

\section{Acknowledgements}

The author C.M. thanks the PhD studentship support from the Department of Employment and Learning for Northern Ireland (DEL); C.C. thanks the strong support from the Central Research Support Funds of Queen's University Belfast via a start-up grant, the support from the Agri-Food Quest Competence Centre R\&D funding programme sponsored by Invest Northern Ireland Agency (Invest NI), and the support from the Queen's University of Belfast AMR Network (QUBAN) sponsored by the UK's Engineering and Physical Sciences Research Council (EPSRC). 


\section{ACCEPTED MANUSCRIPT}

Received: ((will be filled in by the editorial staff))

Revised: ((will be filled in by the editorial staff))

Published online: ((will be filled in by the editorial staff))

\section{Supporting Information}

Comparative overview of DNA detection, using enzyme-assisted, gold nanoparticle-based transducing platform (Table SI. 1.); Comparison of the stability of bare and functionalized gold nanoparticle (AuNP) (Figure SI. 2); AuNP characterization by TEM (Figure SI. 3); Functionalisation of AuNPs with RNA (Figure SI. 4). Information is available from the Elsevier Online Library or from the author.

\section{References}

Baron, E.J., 2011. Journal of clinical microbiology, 49(9), Supplement. S43-S43.

Brooks, B.W., Devenish, J., Lutze-Wallace, C.L., Milnes, D., Robertson, R.H., Berlie-Surujballi, G., 2004. Vet. Microbiol., 103(1-2), 77-84.

Call, D.R., Borucki, M.K., Loge, F.J., 2003. J. Microbiol. Methods, 53(2), 235-243.

Cao, C., Gontard, L.C., Tram, T., Ly, L., Wolff, A., Bang, D.D., 2011. Small, 7(12), 1701-1708.

Cui, L., Ke, G., Zhang, W.Y., Yang, C.J., 2011. Biosensors and Bioelectronics, 26(5), 2796-2800.

Crew, E., Yan, H., Lin, L., Yin, J., Skeete, Z., Kotlyar, T., Tchah, N., Lee, J., Bellavia, M., Goodshaw, I., Joseph, P., Luoa, J., Gal, S., Zhong, C., 2013. DNA assembly and enzymatic cutting in solutions: A gold nanoparticle based SERS detection strategy. Analyst, 138(17), 4941-4949.

Domingos, R.F., Baalousha, M.A,, Ju-Nam, Y., Reid, M.M., Tufenkji, N., Lead, J.R., Leppard, G.G., Wilkinson, K.J., (2009). Environmental science \& technology, 43(19), 7277-7284. 


\section{ACCEPTED MANUSCRIPT}

Dougan, J.A., Karlsson, C., Smith, W.E., Graham, D., 2007. Nucleic Acids Res., 35(11), 3668-3675.

EFSA Panel on Biological Hazards (BIOHAZ), 2011. Scientific Opinion on Campylobacter in broiler meat production: control options and performance objectives and/or targets at different stages of the food chain, EFSA Journal, 4:2105, 1-114.

Fan, Q., Zhao, J., Li, H., Zhu, L., Li, G., 2012. Biosensors and Bioelectronics, 33(1), 211-215.

Fratamico, P.M., 2003. Mol. Cell Probes, 17(5), 215-221.

Huang, Y., Zhao, S., Chen, Z., Shi, M., Chen, J., Liang, H., 2012. Chemical Communications, 48(97), 11877-11879.

Hurst, S.J., Lytton-Jean, A.K.R., Mirkin, C.A., 2006. Analytical chemistry, 78(24), 8313-8318.

Kanaras, A.G., Wang, Z., Brust, M., Cosstick, R., Bates, A.D., 2007. Small, 3(4), 590-594.

Kanaras, A.G., Wang, Z., Hussain, I., Brust, M., Cosstick, R., Bates, A.D., 2007. Small, 3(1), 67-70.

Kim, J., Estabrook, R., Braun, G., Lee, B., Reich, N., 2007. Chem. Commun. (Camb), 14(42), 43424344.

Lauri, A., Mariani, P.O., 2009. Genes \& nutrition, 4(1), 1-12.

Law, J.W., Mutalib, N.A., Chan, K., Lee, L., 2015. Frontiers in microbiology, 5, 770.

Lazcka, O.F., Del Campo, J., and Munoz, F.X., 2007. Biosensors and bioelectronics, 22(7), 12051217.

Lee, J., Han, M.S., Mirkin, C.A., 2007. Angewandte Chemie., 119(22), 4171-4174.

Li, J., Fu, H., Wu, L., Zheng, A., Chen, G., Yang, H., 2012. Anal. Chem., 84(12), 5309-5315.

Li, J., Lu. Y., 2000. Journal of the American Chemical Society, 122(42), 10466-10467. 


\section{ACCEPTED MANUSCRIPT}

Liu, J., Lu, Y., 2003. J. Am. Chem. Soc., 125(22), 6642-6643.

Lu, L., Zhang, X., Kong, R., Yang, B., Tan, W., 2011. Journal of the American Chemical Society, 133(30), 11686-11691.

Lyles, M.M., Gilbert, H.F., 1991. Biochemistry, 30(3), 613-619.

Maurer, J.J., 2011. Annual Review of Food Science and Technology, 2, 259-279.

Mothershed, E.A., Whitney, A.M., 2006. Clinica. Chimica. Acta., 363(1), 206-220.

Ocean Optics (2016). Available online at http://oceanoptics.com/product/usb4000-uv-vis/ [accessed $10 / 08 / 2016]$

Palchetti, I., Mascini, M., 2008. Analyst, 133(7), 846-854.

Pingarrón, J.M., Yañez-Sedeño, P., González-Cortés, A., 2008. Electrochim. Acta., 53(19), 58485866. Rohde, J.A., Appel, B., Dieckmann, R., Al Dahouk, S., 2015. Food Microbiol., 46, 395-407.

Tadokoro, T., Kanaya, S., 2009. Febs. Journal, 276(6), 1482-1493.

Taton, T.A., Mirkin, C.A., Letsinger, R.L., 2000. Science, 289(5485), 1757-1760.

Thaxton, C.S., Georganopoulou, D.G., Mirkin, C.A., 2006. Clinica. Chimica. Acta., 361(1), 120-126.

TSI (2016). Available online at http://tsi.com/optical-particle-sizer-3330/ [accessed 10/08/016]

Turkevich, J., Stevenson, P.C., Hillier, J., 1951. Discuss. Faraday Soc., 11, 55-75.

Verma, M.S., Rogowski, J.L., Jones, L., Gu, F.X., 2015. Biotechnology advances, 33(6), 666-680.

Wang, H., Xu, W., Zhang, H., Li, D., Yang, Z., Xie, X., Li, T., Liu, X., 2011. Small, 7(14), 19871992.

Willner, I., Baron, R., Willner, B., 2006. Adv. Mater, 18(9), 1109-1120. 


\section{ACCEPTED MANUSCRIPT}

World Health Organisation (WHO), 2011. Campylobacter Fact sheet $\mathrm{N}^{\circ} 255$; Available at: http://www.who.int/mediacentre/factsheets/fs255/en/. Accessed 12, 2015.

WTW (2016). Available online at http://www.wtw.com/en/products/product-categories/benchtopmeters/filter-and-spectral-photometers/photolabr-7600-uv-vis.html [accessed 10/08/016]

Wu, S., Tan, S.Y., Ang, C.Y., Luo, Z., Zhao, Y., 2016. Chemical Communications, 52(17), 35083511.

Xu, W., Xue, X., Li, T., Zeng, H., Liu, X., 2009. Angewandte Chemie. International Edition, 48(37), 6849-6852.

Yang, X., Gao, Z., 2014. Nanoscale, 6(6), 3055-3058.

Zayats, M., Baron, R., Popov, I., Willner, I., 2005. Nano Letters, 5(1), 21-25.

Zhao, W., Lam, J.C., Chiuman, W., Brook, M.A., Li, Y., 2008. Small, 4(6), 810-816.

\section{Highlights}

- RNA-functionalized AuNPs is proposed for the detection of bacterial DNA

- Successive hybridization and cleavage reactions between target DNA and RNA by RNAse H

- Resulting in unprotected-AuNPs, which are susceptible to aggregation upon exposure to $\mathrm{NaCl}$

- The method allows naked eye determination of target DNA at concentrations as low as $10^{-6}$ $\mu \mathrm{M}$

- Ultra-high sensitivity at femtomolar level $(2.45 \mathrm{fM})$ can be achieved 